\title{
EKSTRAKSI SENYAWA ANTIOKSIDAN BERUPA LIKOPEN DARI LIMBAH BUAH SEMANGKA DI PULAU LOMBOK
}

\section{[Reproducing Antioxidant Compounds Wit Lycopene Forms From Watermelon Waste In Lombok Island]}

\author{
Taufikul Hadi ${ }^{1) *}$ dan Wardatul Jannah ${ }^{2}$ \\ 1)Prodi Teknik Lingkungan, Fakultas Teknik, UNU NTB \\ 2) Prodi Teknik Lingkungan, Fakultas Teknik, UNU NTB \\ *email: taufikul.hadi17@gmail.com
}

Diterima 26 Oktober 2020 / Disetujui 22 Desember 2020

\begin{abstract}
Watermelon is one of the fruits that are in abundance in the dry season, especially on the island of Lombok. This abundant availability sometimes makes watermelons become waste. One way to take advantage of unsold watermelons so that they do not have to become waste is to extract the antioxidant compounds found in watermelons. The antioxidant compound found in watermelon is lycopene. Lycopene is an antioxidant compound that has many benefits, especially in controlling free radicals in the body. Also, lycopene is useful for preventing cardiovascular disease, diabetes, and, cancer. Lycopene extraction in watermelon fruit waste was carried out by the liquid-liquid method, using Hexane and Ethanol as a solvent with a ratio of 2:1. The purpose of this study was to determine the lycopene content in watermelon waste based on the ratio of feed and solvents (F/S), as well as time and temperature. The ratio of $F / S$ used is 1:1, 1:2, 1:3, 1:4, $1: 5$ extraction temperature $\left(30,40,50,60,70,80\right.$, and 90) ${ }^{\circ} \mathrm{C}$ while the time used $(30,40,50$, $60,70,80,90,100,110,120)$ minutes. Based on the analysis using UV-Vis Spectrophotometry, it is known that the optimum conditions for lycopene content are in the $\mathrm{F} / \mathrm{S}$ ratio of $1: 4$ at $70^{\circ} \mathrm{C}$ and 90 minutes. The lycopene content obtained was 3, $1595 \mathrm{mg} / 100 \mathrm{gram}$.
\end{abstract}

Keywords: antioxidant, extraction, lycopene, UV-Vis spectrophotometry, watermelon

\begin{abstract}
ABSTRAK
Semangka merupakan salah satu buah-buahan yang stoknya melimpah di musim kemarau terutama di pulau Lombok. Ketersediaan yang melimpah tersebut terkadang membuat buah semangka menjadi limbah. Salah satu cara memanfaatkan buah semangka yang tidak laku terjual agar tidak harus menjadi limbah adalah dengan mengekstrak senyawa antioksidan yang terdapat pada buah semangka. Senyawa antioksidan yang terdapat pada buah semangka berupa Likopen. Likopen merupakan senyawa antioksidan yang memiliki banyak sekali manfaat terutama dalam mengendalikan radikal bebas dalam tubuh. Selain itu Likopen juga bermanfaat mencegah penyakit cardiovascular, kencing manis, hingga kanker. Ekstraksi Likopen pada limbah buah semnagka ini dilakukan dengan metode cair-cair, dengan menggunakan Heksana dan Ethanol sebagai pelarut (solvent) dengan jumlah perbandingan 2:1. Adapun tujuan dari penelitian ini adalah untuk bertujuan untuk mengetahui kandungan likopen yang terdapat pada limbah buah semangka berdasarkan perbandingan bahan dan pelarut $(F / S)$, serta waktu dan suhu. Adapun perbandingan $\mathrm{F} / \mathrm{S}$ yang digunakan yaitu $1: 1,1 ; 2,1 ; 3,1: 4,1: 5$ suhu ekstraksi $(30,40,50,60,70,80 \text { dan } 90)^{\circ} \mathrm{C}$ sedangkan waktu yang digunakan (30, 40, 50, 60, 70, 80, 90, 100, 110, 120). Berdasarkan hasil analisa dengan menggunakan Spektrofotometri UV-Vis diketahui bahwa kondisi optimum kandungan Likopen berada pada perbandingan F/S 1:4 pada suhu $700 \mathrm{C}$ dan waktu 90 menit. Kandungan Likopen yang didapatkan sebesar 3,1595 mg/100gram.
\end{abstract}

Kata kunci: antioksidan, ekstraksi, likopen, semangka, spectrofotometri UV-Vis 
Versi Online:

http://www.profood. unram.ac.id/index.php/profood e-ISSN: 2443-3446

\section{PENDAHULUAN}

Persediaan buah semangka di musim kemarau terutama di pulau Lombok sangat melimpah. Karena stok yang melimpah tersebut, banyak buah semangka menjadi busuk karena tidak laku terjual sehingga berakhir menjadi sampah. Salah satu upaya yang bisa dilakukan untuk mengatasi semangka busuk tersebut agar tidak selalu menjadi sampah yang mengganggu lingkungan adalah dengan mengambil senyawa antioksidan yang tersimpan dalam daging buahnya. Senyawa antioksidan yang terdapat dalam buah semangka berupa likopen atau sering disebut a-carotene. Senyawa ini banyak terkandung dalam banyak jenis buah dan sayuran. Buah-buahan yang banyak mengandung likopen selain semangka adalah buah-buahan berwarna merah seperti tomat, jambu biji, papaya, strawberry, dan delima merah (Hamdani \& Rohita, 2013).

Senyawa likopen ini sangat dibutuhkan oleh tubuh untuk mengendalikan radikal bebas, selain itu likopen memiliki manfaat untuk mencegah penyakit cardiovascular, kencing manis, osteoporosis, infertility, dan kanker terutama kanker prostat (Rohatussolihat, 2009., Alfal, 2019). Warna merah pada semangka menandakan tingginya kadar likopen. Karena itu, makan semangka merah lebih disarankan dari pada semangka kuning. Dibandingkan dengan senyawa antioksidan lainnya (khususnya vitamin $\mathrm{C}$ dan E), kekuatan likopen semangka dalam memerangi radikal bebas jauh lebih ampuh. Kekuatannya sebagai antioksidan dua kali lipat dari betakaroten (provitamin A) dan sepuluh kali lipat dibandingkan vitamin E. Jadi, reaksi likopen sebagai antioksidan di dalam tubuh jauh di atas vitamin A, C, E, dan mineral lainnya (Balitbangkes, 2013).

Likopen merupakan suatu antioksidan yang sangat kuat. Kemampuannya mengendalikan singlet oxygen (oksigen dalam bentuk radikal bebas) 100 kali lebih efisien daripada vitamin E atau 12500 kali dari pada gluthation. Singlet oxygen merupakan prooksidan yang terbentuk akibat radiasi sinar ultra violet dan dapat menyebabkan penuaan dan kerusakan kulit. Selain sebagai anti skin aging, likopen juga memiliki manfaat untuk mencegah penyakit cardiovascular, kencing manis, osteoporosis, infertility, dan kanker (kanker kolon, payudara, endometrial, paruparu, pankreas, dan terutama kanker prostat). Ini semua diakibatkan banyaknya ikatan rangkap dalam molekulnya (Mascio, Kaiser, \& Sies, 1989).

Sebagai antioksidan, likopen dapat melindungi DNA, di samping sel darah merah, sel tubuh, dan hati. Selain bermanfaat dalam dunia kesehatan, likopen juga bermanfaat sebagai pewarna makanan dan barang-barang dari plastik. Plastik yang diwarnai dengan likopen tidak akan luntur jika terkena air, sabun, maupun detergent. Namun, warna ini mudah rusak jika dipanaskan pada suhu tinggi, terkena minyak panas, dan bahan oksidator. Selain itu likopen juga bermanfaat sebagai pengawet alami untuk bahan makan semi basah seperti tahu, mie, bakso, ikan, daging serta minyak/lemak (Sayuti dan Yenrima, 2015).

Ektraksi merupakan salah satu metode sederhana dan efektif yang digunakan untuk menganalisis likopen yang terdapat dalam buah dan sayur. Proses ekstraksi itu sendiri merupakan proses pemisahan suatu komponen dari campurannya dengan menggunakan sejumlah mssa bahan (solven) sebagai tenaga pemisah. Menurut Fadilah (2012) proses pemisahan dengan ektraksi terdiri dari tiga langkah dasar yaitu, (1) proses penyampuran sejumlah massa ke adalam larutan yang akan dipisahkan komponen-komponennya, proses pembentukan fase seimbang. proses pemisahan kedua fase seimbang).

Proses ektraksi banyak dipengaruhi oleh beberapa faktor diantaranya jenis pelarut, rasio bahan pelarut, waktu, suhu, ukuran partikel, dan jumlah pelarut (Prasetyiowati dan Tera, 2010). Pada pembentukan likopen, suhu mempunyai peranan penting jika suhu naik maka likopen akan semakin banyak terbentuk (Sari, dkk., 2007). Likopen merupakan senyawa non polar yang mudah larut dalam klorofom, heksana, benzene, etil, asetat, 
Versi Online:

http://www.profood. unram.ac.id/index.php/profood e-ISSN: 2443-3446

aseton, petroleum, eter, dan sebgainya (Jhon Shi dan Marc le Maquer, 2000). Pemisahan likopen dari buah semnagka dapat dilakukan dengan metode ekstraksi cair-cair, menggunakan $\mathrm{n}$-heksan atau etanol sebgai solven serta mengujian kadar likopen dengan menggunakan spektrofotometer (Monica \& Rollando, 2019).

Berdasarkan hal tersebut penelitian ini bertujuan untuk mengetahui kandungan likopen yang terdapat pada limbah buah semangka berdasarakan perbandingan bahan dan pelarut, serta waktu dan suhu. Pada penelitian ini nantinya akan menggunakan pelarut berupa hexsana dan etanhol dengan perbandingan 2:1.

\section{BAHAN DAN METODE}

\section{Alat dan Bahan}

Peralatan yang digunakan dalam penelitian ini adalah Blender, Beaker Glass, Labu takar, Erlenmeyer, Gelas ukur, Timbangan, Strirrer, Spektrofotometer, Corong gelas, Piknometer, Pipet, Corong, Aluminium Foli, dan Kertas Saring. Adapun rangkaian alat yang digunakan seperti yang terlihat pada Gambar 1 berikut:

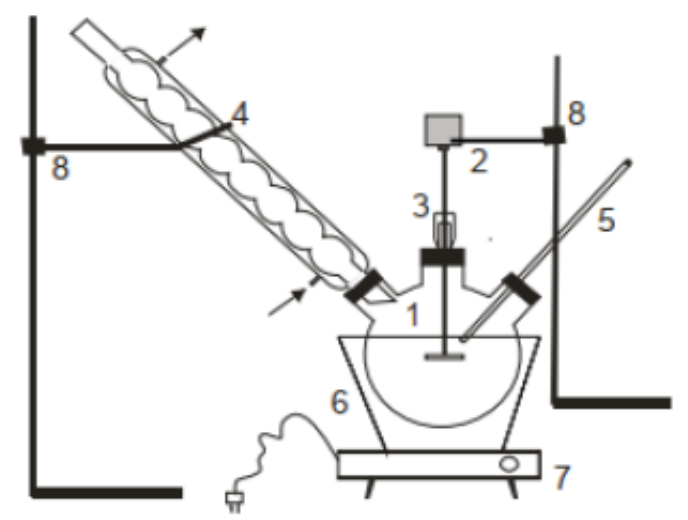

Gambar 1. Rangkaian Alat

Keterangan:

1. Labu leher tiga

2. Motor pengaduk

3. Pengaduk Merkuri

4. Pendingin balik

5. Termometer

6. Waterbath

7. Kompor listrik

8. Statif dan klem
Adapun bahan yang digunakan dalam penelitian ini limbah semangka yang sudah dibuat jus, bahan pelarut berupa etanhol dan heksana.

\section{Prosedur Pelaksanaan}

1. Penentuan Perbandingan F/S, Suhu, dan Waktu Ektraksi Optimal

Limbah buah semangka yang sudah dihaluskan dengan blender dicampur dengan solvent yang sudah dibuat perbandingannya $\mathrm{F} / \mathrm{S}(1: 1,1: 2,1: 3,1: 4$, $1: 5)$, kemudian mengatur suhu pemanasan sesuai dengan variable yang sudah ditentukan yaitu $(30,40,50,60,70,80)^{\circ} \mathrm{C}$ dan menjalankan proses ektraksi selama 1 jam utuk tiap variabel suhu. Campuran dipindahkan ke dalam corong pisah, ditambahakan dengan $10 \mathrm{ml}$ aquades, dikocok kembali dan didiamkan selama 15 menit sampai terbentuk dua fase. Lapisan atas (nonpolar) diambil dan dimasukkan dalam labu ukur $100 \mathrm{ml}$ sambil ditambahkan dengan etanhol sampai tanda batas yang ditentukan. Dengan menggunakan Spektrofotometer UV-Vis pada panjang gelombang maksimum 470 $\mathrm{nm}$ dapat ditentukan kadar likopen total dari lapisan bagian atas (nonpolar) pada tiap-tiap variable suhu. Dari hasil Analisa dapat ditentukan perbandingan F/S optimal pada 1: 4 dengan suhu $70^{\circ} \mathrm{C}$. Hasil ini kemudian dilanjutkan untuk menentukan waktu optimal $(30,40,50,60,70,80,90$, $100,110,120$ menit) dengan menggunakan langkah-langkah yang sama, akan tetapi menggunakan perbandingan F/S (1:4) pada suhu $70^{\circ} \mathrm{C}$.

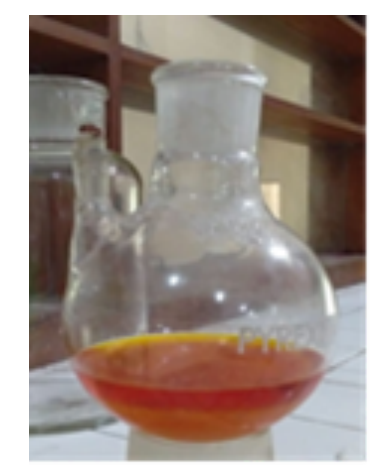

Gambar 2. Hasil Ektraksi 
Versi Online:

http://www.profood. unram.ac.id/index.php/profood e-ISSN: 2443-3446

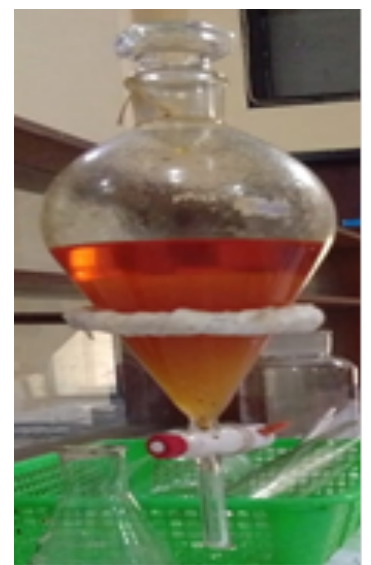

Gambar 3. Proses Pemisahan Hasil Ektraksi

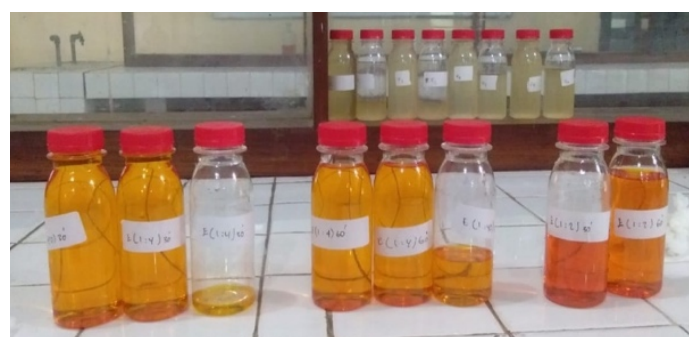

Gambar 4. Hasil akhir pemisahan

2. Analisa Antioksidan dengan

Spektrofotometri UV-Vis (Stahl, 1985)

Sampel yang telah bebas endapan sebanyak $5 \mathrm{ml}$ diencerkan dengan Hexana sampai $25 \mathrm{ml}$, hasil pengenceran tersebut kemudian dimasukkan ke dalam cuvet dan dianalisisa dengan menggunakan spektronik C-20 pada Panjang gelombang $470 \mathrm{~nm}$. Kemudian dilanjutkan dengan mengkalibrasi data absorbansi dalam kadar larutan likopen standar.

\section{HASIL DAN PEMBAHASAN}

Proses ektraksi kandungan likopen pada limbah buah semangka dilakukan dengan menggunakan ektraksi ektraksi cair-cair. Ektraksi cair-cair merupakan proses pemisahan fase cair yang memanfatkan perbedaan kelarutan zat yang akan dipisahkan antara larutan asal dan pelarut pengekstrak (Mirwan \& Arriono, 2010). Adapaun solvent yang digunakan pada penelitian ini adalah heksana dan ethanol dengan perbandingan 2:1. Hasil ektraksi dipisahkan antara lapisan polar dan nonpolar dengan menggunakan corong pisah seperti pada gambar 3. Selanjutnya bagian atas (nonpolar) ditampung pada gelas ukur $100 \mathrm{ml}$ ditambahakna dengan ethnol sampai tanda batas seperti pada gambar 4 . Selanjutnya bagian non polar tersebut dianalisa dengan spektrofotometri UV-Vis pada Panjang gelombang $470 \mathrm{~nm}$ dengan berbagai perlakuan diantaranya berdasarakan perbedaan perbandingan $\mathrm{F} / \mathrm{S}$, perbedaan suhu, serta perbedaan waktu ekstraksi.

\section{Perbandingan Bahan dan Pelarut (F/S) Optimum Pada Kadar Likopen}

Dengan menggunakan spektrofotometer pada panjang gelombang $470 \mathrm{~nm}$ diperoleh data absorbansi jus limbah buah semangka sebesar 0,996 dengan kadar total likopen $15,24 \mathrm{mg} / 100 \mathrm{gr}$. Selanjutnya dari hasil analisa diketahui perbandingan F/S (1:4) mampu mengekstrak likopen dengan jumlah lebih besar. Sedangkan pada perbandingan F/S (1:1), (1:2), dan (1:3), kondisinya belum optimal dikarenakan jumlah jus limbah semangka (bahan) lebih banyak daripada jumlah pelarutnya sehingga tidak semua likopen dapat dilarutkan oleh pelarut. Begitu juga pada perbandingan F/S (1:5), kandungan likopen yang dihasilkan lebih kecil dari perbandingan $F / S$ (1:4). Hal seperti ini juga terjadi pada penelitian yang dilakukan oleh Maulida \& Zulkarnaen (2010) yang mengekstraksi kandungan likopen pada buah tomat. Hasil penelitiannya menunjukkan bawah kandungan kadar likopen pada buah tomat optimum terekstraksi pada kondisi perbandingan $F / S \quad 1: 4$, sedangkan pada perbandingan $\mathrm{F} / \mathrm{S}$ 1:5 mengalami penurunan. Begitu juga pada penelitian yang dilakukan oleh Hamsina, dkk (2019) yang mengekstraksi likopen pada buah semangka, kandungan likopen optimal terjadi pada kondisi perbandingan $F / S \quad 1: 2$, sedangkan pada perbandingan $F / S$ 1:3 mengalami penurunan. Hasilnya terlihat menurun karena volume pelarut yang digunakan semakin besar akibatnya semakin banyak impuritas yang ikut terlarut. Hal ini akan menyebabkan terjadinya perubahan sifat komponen dari likopen. Berikut disajikan data absorbansi Likopen 
dengan perbandingan bahan dan pelarut (F/S) dengan berbagai jumlah perbandingan $F / S$.

Tabel 1. Data absorbansi likopen dengan F/S

\begin{tabular}{|c|c|c|c|c|}
\hline $\begin{array}{c}\text { Rasio } \\
\text { F/S }\end{array}$ & \begin{tabular}{|c|} 
Temper \\
atur \\
$\left({ }^{\circ} \mathrm{C}\right)$
\end{tabular} & $\begin{array}{c}\text { Absorbansi(470 } \\
\mathrm{nm})\end{array}$ & $\begin{array}{l}\text { Kadar Total } \\
\text { Likopen } \\
\text { (mg/100gr) }\end{array}$ & $\begin{array}{c}\text { Persentase } \\
\text { kadar } \\
\text { Likopen } \\
(\%)\end{array}$ \\
\hline \multirow{6}{*}{$1: 1$} & 30 & 0,1615 & 0,9767 & 6,41 \\
\hline & 40 & 0,1631 & 1,0030 & 6,58 \\
\hline & 50 & 0,1646 & 1,0293 & 6,75 \\
\hline & 60 & 0,1669 & 1,0688 & 7,01 \\
\hline & 70 & 0,1692 & 1,1082 & 7,27 \\
\hline & 80 & 0,1650 & 1,0359 & 6,80 \\
\hline \multirow[t]{6}{*}{$1: 2$} & 30 & 0,1846 & 1,3712 & 9,00 \\
\hline & 40 & 0,1869 & 1,4107 & 9,26 \\
\hline & 50 & 0,1854 & 1,3844 & 9,08 \\
\hline & 60 & 0,2000 & 1,6342 & 10,72 \\
\hline & 70 & 0,2008 & 1,6473 & 10,81 \\
\hline & 80 & 0,1985 & 1,6079 & 10,55 \\
\hline \multirow[t]{6}{*}{$1: 3$} & 30 & 0,2308 & 2,1602 & 14,17 \\
\hline & 40 & 0,2315 & 2,1733 & 14,26 \\
\hline & 50 & 0,2308 & 2,1602 & 14,17 \\
\hline & 60 & 0,2377 & 2,2785 & 14,95 \\
\hline & 70 & 0,2438 & 2,3837 & 15,64 \\
\hline & 80 & 0,2400 & 2,3179 & 15,21 \\
\hline \multirow[t]{6}{*}{$1: 4$} & 30 & 0,2315 & 2,1733 & 14,26 \\
\hline & 40 & 0,2538 & 2,5546 & 16,76 \\
\hline & 50 & 0,2769 & 2,9491 & 19,35 \\
\hline & 60 & 0,2815 & 3,0267 & 19,86 \\
\hline & 70 & 0,2838 & 3,0675 & 20,13 \\
\hline & 80 & 0,2815 & 3,0280 & 19,87 \\
\hline $\begin{array}{c}\text { Rasio } \\
\text { F/S }\end{array}$ & \begin{tabular}{|c|} 
Temper \\
atur \\
$\left({ }^{\circ} \mathrm{C}\right)$
\end{tabular} & $\begin{array}{c}\text { Absorbansi } \\
(470 \mathrm{~nm})\end{array}$ & $\begin{array}{l}\text { Kadar Total } \\
\text { Likopen } \\
\text { (mg/100gr) }\end{array}$ & $\begin{array}{c}\text { Persentase } \\
\text { kadar } \\
\text { Likopen } \\
(\%)\end{array}$ \\
\hline \multirow[t]{6}{*}{$1: 5$} & 30 & 0,2546 & 2,5678 & 16,85 \\
\hline & 40 & 0,2550 & 2,5744 & 16,89 \\
\hline & 50 & 0,2538 & 2,5546 & 16,76 \\
\hline & 60 & 0,2423 & 2,3574 & 15,47 \\
\hline & 70 & 0,2323 & 2,1865 & 14,35 \\
\hline & 80 & 0,2277 & 2,1076 & 13,83 \\
\hline
\end{tabular}

\section{Suhu Optimum Hasil Ekstraksi Likopen}

Proses ekstraksi limbah buah semangka pada penelitian ini menggunakan suhu 30,40 , $50,60,70,80^{\circ} \mathrm{C}$. Berdasarkan dari tabel $1 \mathrm{di}$ atas dapat diketahui bahwa jumlah hasil ekstraksi terbesar diperoleh pada suhu $70^{\circ} \mathrm{C}$ di setiap perbandingan $\mathrm{F} / \mathrm{S}$ yang telah ditentukan kecuali di perbandingan F/S 1:5 hasil ekstraksi terbesar terjadi pada suhu $40^{\circ} \mathrm{C}$. Data kadar likopen pada masing-masing perbandingan dan suhu lebih jelasnya disajikan pada Gambar 5.

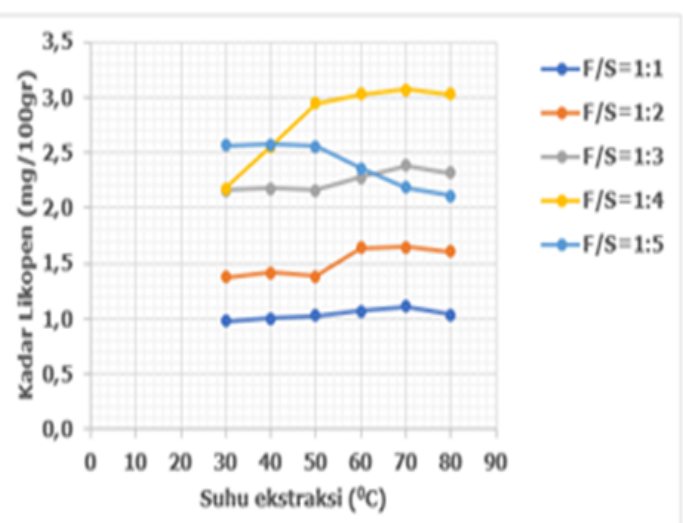

Gambar 5. Grafik Kadar Likopen dan suhu ekstraksi

Dari grafik di atas terlihat pada suhu $80^{\circ} \mathrm{C}$ di setiap perbandingan $\mathrm{F} / \mathrm{S}$ hasil ekstraksi yang dihasilkan mengalami penurunan. Hal ini dikarenakan kenaikan suhu akan menyebabkan dekomposisi dari komponen likopen yang menyebabkan komponen baru lebih rendah dari titik didih komponen sebelumnya sehingga menjadi lebih mudah menguap (Maulida \& Zulkarnaen, 2010).

\section{Waktu Optimum Hasil Ektraksi Likopen}

Perbandingan F/S 1:4 dan suhu ekstraksi $70^{\circ} \mathrm{C}$ digunakan untuk menentukan kadar likopen pada berbagai macam rentang waktu. Pada penelitian ini menggunakan waktu ekstraksi dengan rentang 30,40, 50, 60, 70, $80,90,100,110,120$ menit dan selanjutnya memilih waktu yang optimum dalam menghasilkan kadar likopen.

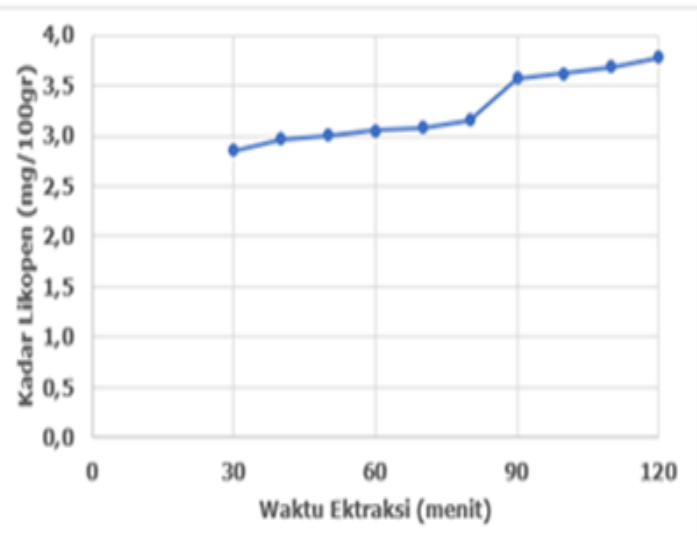

Gambar 6. Grafik waktu ekstraksi terhadap kadar likopen 
Dari Gambar 6 terlihat semakin lama waktu ektraksi yang digunakan maka semakin banyak hasil ekstraksi yang diperoleh. Hal ini disebabkan oleh lamanya waktu kontak antara pelarut (solvent) dan bahan terlarut (solute) yang mengakibatkan proses pelarutan likopen oleh pelarut akan terus terjadi sampai pelarut setimbang terhadap bahan pelarut. Hal ini sesuai dengan yang dikemukakan oleh Handayani, et all (2014), menyatakan bahwa semakin lama waktu ekstraksi maka kesempatan bahan kontak dengan pelarut akan semakin besar sehingga rendemen hasil ekstraksi juga akan bertambah. Begitu juga yang dilaporkan oleh Kojic, et all (2011) bahwa suhu dan waktu ekstraksi memiliki peranan yang penting dalam proses ekstraksi, Terlalu singkatnya waktu ekstraksi mengakibatkan pelarutan senyawa antioksidan tidak optimum sehingga bahan belum terekstraksi secara sempurna dan sebaliknya, semakin lama waktu ekstraksi maka akan menaikkan jumlah analit yang terekstrak karena kontak antara solven dan solute akan semakin lama sehingga proses pelarutan senyawa antioksidan akan terus berlangsung dan berhenti sampai pelarut jenuh. Adapun hasil ekstraksi yang didapatkan dari masing-masing waktu tersebut adalah 2,8571; 2,9715; 3,0109; 3,0543; 3,0806; 3,$1595 ; \quad 3,5750 ; \quad 3,6197 ; \quad 3,6855 ; \quad 3,775$ $\mathrm{mg} / 100 \mathrm{gr}$.

Waktu optimal dari proses ekstraksi terjadi pada waktu ekstraksi selama 90 menit. Hal ini terlihat dalam gambar 6 di atas, meskipun waktu ekstraksi 100, 110 dan 120 menit menghasilkan kadar likopen lebih besar namun peningkatannya tidak terlalu berbeda dengan kadar likopen yang dihasilkan pada waktu ekstraksi 90 menit. Penggunaan waktu ekstraksi yang lebih lama dari 90 menit justru akan membuat waktu operasi semakin lama sehingga menjadi tidak efisien dan ekonomis.

\section{KESIMPULAN}

Limbah buah semangka dapat dimanfaatkan kembali dengan mengekstrak senyawa antioksidan berupa likopen yang ada pada daging buahnya. Kondisi optimum kandungan likopen pada limbah buah semangka terjadi pada kondisi perbandingan F/S (1:4) pada suhu $70^{\circ} \mathrm{C}$ dan waktu 90 menit dengan jumlah kandungan likopen sebesar 3 , $1595 \mathrm{mg} / 100 \mathrm{gram}$.

\section{UCAPAN TERIMAKASIH}

Ucapan terimakasih pada KEMENRISTEK BRIN yang telah memberikan bantuan dana dalam skema penelitian dosen pemula untuk tahun 2020.

\section{DAFTAR PUSTAKA}

Alfal. 2019. Likopen, Antioksidan eksogen yang bermanfaat bagi kesehatan fertilitas Laki-laki. Jurnal Majority. 8(1): 12-22.

Balitbangkes Republik Indonesia. 2013. Laporan hasil riset kesehatan.

Di Mascio, P., Kaiser, S., Sies, H., 1989. Lycopene as The Most Efficient Biological Carotenoid Singlet Oxygen Quencher. Archives of Biochemistry and Biophysics.

Fadilah, A.N. 2012. Isolasi dan Purifikasi likopen dari buah tomat dan semangka. Skripsi. Universitas Indonesia. Jakarta.

Hamsina., Ruslan, Hasani., Irfan. 2019. Optimasi Proses Ekstraksi Senyawa Likopen dari Buah Semangka dengan Menggunakan Variasi Pelarut. Prosiding Seminar nasional Penelitian \& Pengabdian kepada Masyarakat. 59-63.

Handayani, D., Mun'im, A., Ranti, A. S. 2014. Optimation of green tea wate extraction using microwave assisted extraction to yield green tea extract. Traditional Medicine Journal 19(1): 29-35.

Kojic, A. B., Mirela, P., Srecko, T., Stela, K., Ibrahim, M., Mate, B., Darko, V. 2011. Effect of extraction conditions on the extractability of phenolic compounds from lyophilised fig fruits (Ficus carcia L). Journal Food Nutrition Science 61(3): 195-199.

Maulida, D., Zulkarnaen, N. 2010. Eksraksi Antioksidan (Likopen) Dari Buah Tomat Dengan Menggunakan Solven Campuran, n-Heksana, Aseton, dan Etanol. Skripsi. Fakultas Teknik. Universitas Diponegoro. Semarang. 
Mirwan, A., Arriono, D. 2010. Dinamika Tetes Ekstraksi Cair-Cair Sistem Air-Metil Keton (Mek)-Heksan Dalam kolom Isian. Jurnal Teknik kimia Indonesia 9(3): 100.

Monica, E., Rollando. 2019. Identifikasi dan Isolasi Senyawa Likopen dari Semangka (Citrullus Lanatus). Jurnal IImu Farmasi dan farmasi Klinik 16(1): 80-85.

Prasetyowati, R.P., Tera,F. 2010. Pengambilan Minyak Biji Alpukat (Persea Americana Mill) dengan Metode Ekstraksi. Jurnal Teknik Kimia. 17(2): 16-24.

Rohatussolihat. 2009. Antioksidan penyelamat sel-sel tubuh manusia. Jurnal Biotrends. 4(1): 5-9.

Sari, A., Kun, T.D., Sunarmani. 2007. Potensi Likopen dalam Tomat Untuk Kesehatan. Buletin Teknologi Pascapanen Pertanian. 3(11).

Sayuti, K., Yenrina, R. 2015. Antioksidan Alami Dan Sintetik. Andalas university Press. Padang.

Shi, J., Maquer, M.L. 2000. Lycopene in Tomatoes: Chemical and Physical Properties Affected by Food Processing. Critical Reviews in Biotechnology. 20(4): 293-334.

Stahl, E. 1985. Analisis Obat Secara kromatografi dan Mikroskopi, diterjemahkan oleh Kosasih Padmawinata dan Iwang Soediro. 3-17. ITB. Bandung

Tristiyani, D., Hamdani., dan Rohita D. 2013. Penetapan kadar likopen dari beberapa buah berdaging merah dengan metode spektrofotometri. JTFSI. 2(2): 11-21. 